\title{
Effects of Staphylococcal $\alpha$-Toxin on the Structure of Erythrocyte Membranes: a Biochemical and Freeze-etching study
}

\author{
By J. H. FREER, J. P. ARBUTHNOTT AND BRONWEN BILLCLIFFE \\ Department of Microbiology, University of Glasgow, \\ Alexander Stone Building, Garscube Estate, Bearsden, Glasgow
}

(Received 14 September 1972)

SUMMAR Y

A correlated electron microscopy and biochemical study of the effects of staphylococcal $\alpha$-toxin on rabbit erythrocyte membrane structure has been carried out. Using several criteria, no evidence was obtained for the involvement of a proteolytic mechanism in the mode of action of this toxin.

After toxin treatment, ghosts examined by freeze-etching showed changes in micromorphology consistent with a hydrophobic interaction between toxin and membrane.

\section{INTRODUCTION}

An earlier study showed that interaction of staphylococcal $\alpha$-toxin with erythrocyte ghosts resulted in membrane fragmentation, binding of toxin and the appearance on membrane fragments of ring structures morphologically identical to the $\alpha_{128}$ polymer of the toxin (Freer, Arbuthnott \& Bernheimer, I968). In the same study, similar results were obtained using artificial membranes composed only of lipids (liposomes) as a target for toxin. Also, the interaction of toxin with mixed monolayers of lipids resulted in changes in surface charge and pressure which indicated that the toxin possessed a high degree of surface activity. This aspect has since been investigated in detail by Colacicco and his colleagues (Buckelew \& Colacicco, I97I; Colacicco \& Buckelew, I97I), who confirmed the high surface activity of this protein.

With regard to the cytolytic mechanism of $\alpha$-toxin, the key question is whether the demonstrated surface activity is sufficient to account for its biological activity, or whether an additional enzymatic mechanism is also involved (see Wiseman \& Caird, I970, 1972).

The present study was undertaken in order to investigate two aspects of this problem: (i) the possibility of detecting evidence of hydrophobic interaction between toxin and erythrocyte membranes using the technique of freeze-etching, which reveals the interior hydrophobic regions of the membranes (Branton, 197I); and (ii) following the reports of Wiseman \& Caird (1970, 1972) that a proteolytic mechanism is involved in the mode of action of $\alpha$-toxin, to detect whether changes occur in membrane polypeptides after toxin/ membrane interaction, and to compare the effects of known proteolytic enzymes with those of $\alpha$-toxin on the erythrocyte membrane.

\section{METHODS}

Staphylococcal $\alpha$-toxin. Pure toxin was obtained from culture supernatants of Staphylococcus aureus strain Wood 46 as described previously (McNiven, Owen \& Arbuthnott, 1972). The method for purification involved isoelectric focusing of crude toxin prepared by ammonium sulphate precipitation of culture filtrates. The purified toxin was free from 
contaminating staphylococcal extracellular products, gave a single precipitin line against commercially available $\alpha$-antitoxin (Wellcome Research Laboratories, Beckenham, Kent) and showed a major and a minor peak by polyacrylamide disc gel electrophoresis in the presence of sodium dodecyl sulphate (SDS) corresponding to the $\alpha_{3 \mathrm{~s}}$ monomer and the $\alpha_{12 s}$ polymer respectively (see Arbuthnott, Freer \& Billcliffe, I973).

Erythrocyte ghost preparations. Erythrocyte ghost fractions were prepared from fresh rabbit blood by a method based upon that of Hoogeveen, Juliano, Coleman \& Rothstein (1970). Fresh rabbit blood was centrifuged at $1500 \mathrm{~g}$ for $10 \mathrm{~min}$ at room temperature, and the plasma and buffy coat layer carefully removed by aspiration. The remaining pellet was gently resuspended in $20 \mathrm{vol}$. of $0.85 \%(\mathrm{w} / \mathrm{v}) \mathrm{NaCl}$ and the centrifugation and aspiration process repeated. The sedimented erythrocytes were then washed twice in $0.85 \%(\mathrm{w} / \mathrm{v}) \mathrm{NaCl}$. Erythrocytes were lysed by slow dropwise addition of the packed cells to $200 \mathrm{vol}$. of $0.0 \mathrm{I} \mathrm{M}$ phosphate buffer, $\mathrm{pH}_{7} \cdot 4$, which was stirred slowly throughout this step. Centrifugation ( $39000 \mathrm{~g}$ for $15 \mathrm{~min}$ ) of the resulting lysate gave a light buff-coloured membrane pellet which was resuspended and washed a further twice with 200 vol. of $0.01 \mathrm{M}$-tris/ $\mathrm{HCl}$ buffer, $\mathrm{pH} \mathrm{7*4}$. Erythrocyte ghosts prepared in this way were haemoglobin-free as assessed by polyacrylamide disc gel electrophoresis, and were used immediately after preparation.

Reaction mixtures. Samples for polyacrylamide disc gel electrophoresis were taken from reaction mixtures prepared as follows. To $0.2 \mathrm{ml}$ of erythrocyte ghost suspension, containing approximately $500 \mu \mathrm{g}$ of protein (Lowry, Rosebrough, Farr \& Randall, I95I), was added $0 . \mathrm{I} \mathrm{ml}$ of $0.03 \mathrm{M}$-sodium borate buffer, $\mathrm{pH} \mathrm{8.3}$, and either $0.1 \mathrm{ml}$ of $\alpha$-toxin [100 $\mu \mathrm{g}$ protein, 2500 Haemolytic Units (HU)] or 0. I ml of enzyme solution of the appropriate concentration. The reactants were mixed and incubated at $37^{\circ} \mathrm{C}$ for $30 \mathrm{~min}$, after which time samples were taken for disc gel electrophoresis.

Polyacrylamide disc gel electrophoresis. After the incubation period, $0.02 \mathrm{ml}$ of $0.1 \mathrm{M}-$ phenylmethane sulphonyl fluoride was added to the reaction mixtures in order to inhibit further enzymatic activity. The mixture was then made up to $0.8 \mathrm{ml}$ with $0.03 \mathrm{M}$-sodium borate buffer, $\mathrm{pH} 8.3$, and $0 . \mathrm{I} \mathrm{ml} 20 \%$ (w/v) SDS, $0 . \mathrm{I} \mathrm{ml} \mathrm{I} 6 \%(\mathrm{v} / \mathrm{v})$ mercaptoethanol, and $0.1 \mathrm{ml}$ of glycerol were added with stirring. Samples of $0 . \mathrm{I} \mathrm{ml}$ of these mixtures were then carefully layered on to gels before starting electrophoresis. The procedure used for electrophoresis was that described by McNiven et al. (1972) using a separating gel containing II $\cdot 7 \%$ (w/v) acrylamide (B.D.H., Poole, Dorset) and $0.153 \%(\mathrm{w} / \mathrm{v}) N^{\prime}$-methylenebisacrylamide (B.D.H.). Stacking gels were strengthened by the method of DeVito \& Santomé (I966), but without the addition of ethylene diamine tetraacetate. The gels and the buffer system were made $0 \cdot 1 \%(w / v)$ with respect to SDS. A current of $1 \mathrm{~mA}$ was applied to each gel and when the tracking dye reached $10 \mathrm{~mm}$ from the base of the gel, the current was increased to $5 \mathrm{~mA} / \mathrm{gel}$ for $\mathrm{I} 5 \mathrm{~min}$ before termination of the run. Gels were fixed and stained overnight in either a solution containing I \% (w/v) Amido Black B and $10 \%(\mathrm{v} / \mathrm{v})$ acetic acid in $50 \%(\mathrm{v} / \mathrm{v})$ methanol or in a solution containing $0.25 \%(\mathrm{w} / \mathrm{v})$ Coomasie Brilliant Blue and $10 \%(\mathrm{v} / \mathrm{v})$ acetic acid in $45 \%(\mathrm{v} / \mathrm{v})$ methanol. After fixation and staining gels were rehydrated in $7 \%$ (v/v) acetic acid prior to electrophoretic destaining (Berg, I969). Densitometer traces of gels were made using a Joyce-Loebl u.v. Polyfrac scanner linked to a Bryan's potentiometric recorder.

Protein estimations. Erythrocyte ghost protein was estimated (Lowry et al. 195I) after membrane suspensions had been clarified by the addition of SDS to a final concentration of $2.0 \%(\mathrm{w} / \mathrm{v})$. Bovine serum albumin fraction V (Armour Pharmaceutical Co. Ltd, Eastbourne, Sussex) was used as a standard.

Quantitative changes in sedimentable protein. Reaction mixtures were prepared as described 
for disc gel electrophoresis and diluted to a final volume of $0.8 \mathrm{ml}$ with $0.03 \mathrm{M}$-sodium borate buffer, $\mathrm{pH} 8 \cdot 3$. The samples were then centrifuged at $48000 \mathrm{~g}$ for $\mathrm{I} 5 \mathrm{~min}$ and the supernatant fraction carefully separated from the pellet. Sedimentable protein was estimated after clarification of the pellet by the addition of SDS to a final concentration of $2 \cdot 0 \%(\mathrm{w} / \mathrm{v})$.

Enzyme treatment of washed erythrocytes. Enzyme treatment of whole erythrocytes prior to kinetic experiments was carried out in a mixture containing $4.9 \mathrm{ml}$ of $0.7 \%(\mathrm{v} / \mathrm{v})$ washed rabbit erythrocytes in tris-buffered saline $(0.85 \%(\mathrm{w} / \mathrm{v})$ sodium chloride in $0.0 \mathrm{I} \mathrm{M}$-tris $/ \mathrm{HCl}$ buffer, $\mathrm{pH} 7.4)$ and $0 . \mathrm{I} \mathrm{ml}(500 \mu \mathrm{g})$ of either pronase (B.D.H.), Subtilisin, or trypsin (Sigma Chemical Co., St Louis, Missouri, U.S.A.). After incubation at $37^{\circ} \mathrm{C}$ for $30 \mathrm{~min}$, the cells were sedimented by centrifugation at $1500 \mathrm{~g}$ for $10 \mathrm{~min}$, and then washed twice in trisbuffered saline prior to resuspension in the same solution to a concentration of $0.7 \%(\mathrm{v} / \mathrm{v})$.

Kinetics of haemolysis. Reaction mixtures for measurements of the kinetics of haemolysis consisted of $\mathrm{I} \cdot 3 \mathrm{ml}$ tris-buffered saline, $0 . \mathrm{I} \mathrm{ml}$ of $0.7 \%(\mathrm{v} / \mathrm{v})$ washed rabbit erythrocytes (either treated or untreated with the appropriate enzyme prior to addition) and $0.1 \mathrm{ml}$ of the appropriate dilution of $\alpha$-toxin. The toxin was added last to the cuvette, and after rapid mixing of the contents, the $E_{650}^{1 \mathrm{~cm}}$ was continuously recorded at room temperature on a Pye Unicam S.P. 800 spectrophotometer. The dilution of toxin used was that which gave complete haemolysis within 5 to $10 \mathrm{~min}$.

Negative staining. Samples were negatively stained by a modification of the method of Brenner \& Horne(I959), diluting with $2 \cdot 0 \%$ (w/v) ammonium molybdate to yield a slightly turbid suspension, and a drop of this was applied to a grid covered with carbon-coated formvar. Sufficient suspension was withdrawn with a filter paper point to leave a thin film on the grid, which dried within $5 \mathrm{~s}$. Grids were examined immediately after preparation.

Freeze-etching. Samples (10 $\mu \mathrm{l})$ of reaction mixtures were applied to gold specimen support discs using a fine capillary pipette, and were immediately rapidly frozen by immersion for 2 to $3 \mathrm{~s}$ in Freon 22 at liquid nitrogen temperature. The specimens were then rapidly transferred to liquid nitrogen and stored until used $(<2 \mathrm{~h})$. Freeze-fracturing and etching were carried out in a Balzer's $360 \mathrm{M}$ Freeze-Etch Unit, with a specimen temperature of $-100{ }^{\circ} \mathrm{C}$ during the fracturing and etching process. Replication was started immediately after the last fracture stroke or, in the case of etched specimens, after I min of etching. After floating on to distilled water, the replicas were cleaned by overnight immersion in a $5.0 \mathrm{mg} / \mathrm{ml}$ solution of Subtilisin, followed by transfer to a $5.0 \%(\mathrm{w} / \mathrm{v})$ solution of SDS (4 to $6 \mathrm{~h})$, and finally to a solution of $70 \%(\mathrm{v} / \mathrm{v})$ sulphuric acid $(5 \mathrm{~h})$. After this cleaning procedure, the replicas were given three rinses in distilled water prior to collection on grids carrying carbon-coated formvar films.

Embedding and thin sectioning. To $4.8 \mathrm{ml}$ of $0.8 \%(\mathrm{v} / \mathrm{v})$ washed rabbit erythrocytes was added $0.2 \mathrm{ml}(4000 \mathrm{HU})$ of $\alpha$-toxin. After rapid mixing $0.13 \mathrm{ml}$ of the reaction mixture was withdrawn and added to $1.4 \mathrm{ml}$ of tris-buffered saline and the kinetics of haemolysis were followed as described above. At the onset of haemolysis (after $30 \mathrm{~s}$ ) the remainder of the reaction mixture was fixed for $4 \mathrm{~h}$ at room temperature after addition of $0 \cdot \mathrm{I} \mathrm{ml}$ of $25 \%(\mathrm{v} / \mathrm{v})$ glutaraldehyde. The fixed erythrocytes were washed thoroughly in veronal-acetate buffer (Kellenberger, Ryter \& Séchaud, I958) and postfixed for I h at room temperature in I \% (v/v) osmium tetroxide in the same buffer. Specimens were then stained, dehydrated, embedded and sectioned as described earlier (Freer et al. 1969).

All specimens were examined in a Philip's EM 300 electron microscope operating at $60 \mathrm{kV}$. 

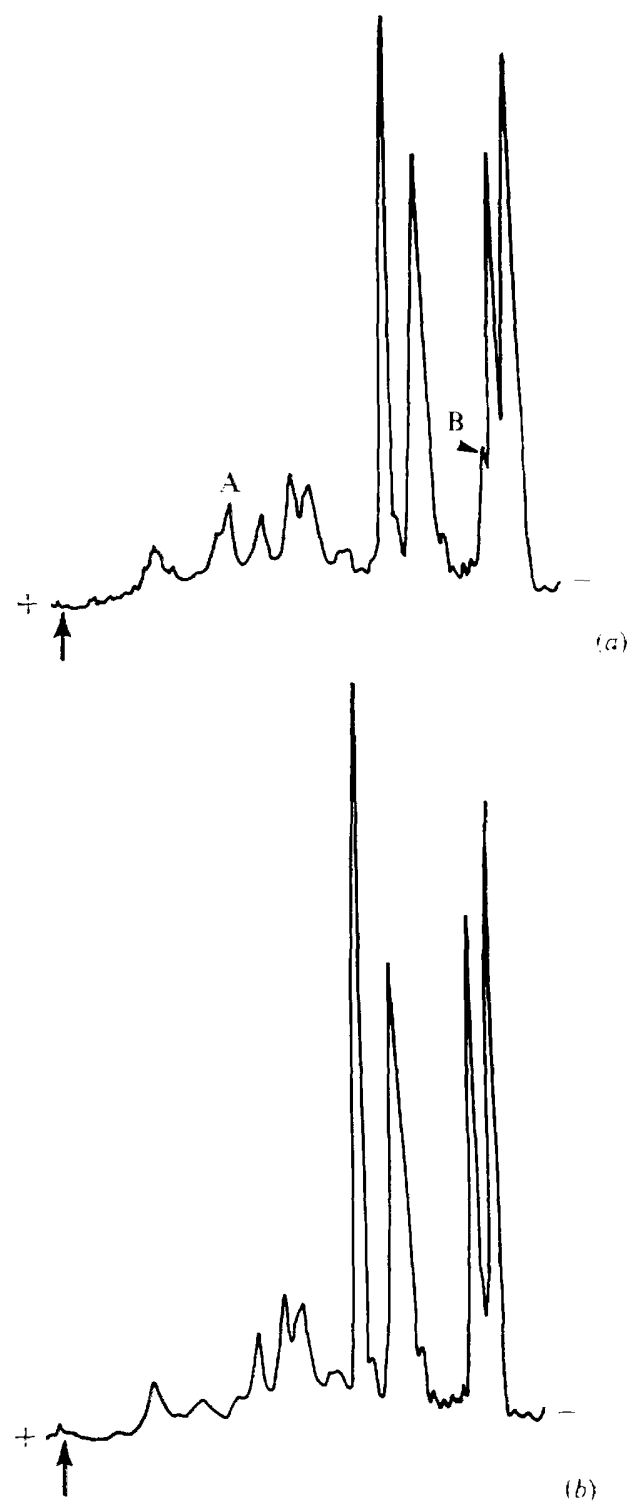

(b)

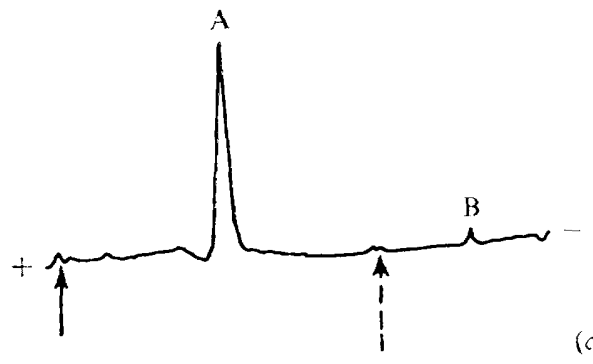

(c)

Fig. I. Densitometer traces of SDS polyacrylamide disc gels stained with Coomasie Brilliant Blue of reaction mixtures (Methods) containing: (a) rabbit erythrocyte ghosts $+\alpha$-toxin; $(b)$ rabbit erythrocyte ghost control; (c) $\alpha$-toxin control. Traces were recorded on a Bryan's recorder set at $4 \mathrm{~V}$ at a speed of $\mathrm{I} \mathrm{mm} / \mathrm{s}$ using a Joyce-Loebl u.v. Polyfrac scanner. A, fast moving $\alpha$-toxin component $(\mathrm{mol}$. wt $=36000)$; B, slow moving $\alpha$-toxin component $(\mathrm{mol}$. wt $=170000)$. $\uparrow$, Position of tracking dye bromophenol blue; $\hat{i}$, gel artefact; + , anode; - , cathode. 


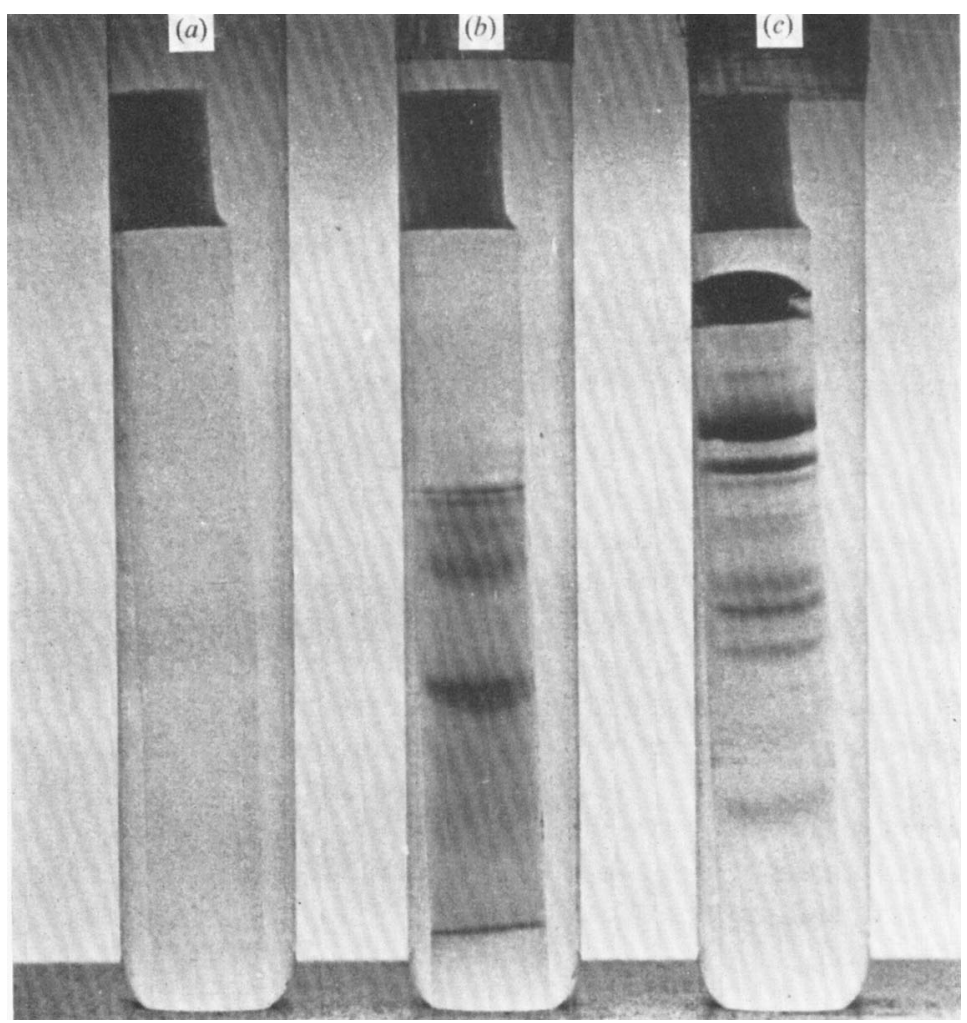

Fig. 2. SDS polyacrylamide disc gels showing the effect of pronase on rabbit erythrocyte ghosts. (a) Erythrocyte ghosts treated with $100 \mu \mathrm{g}$ pronase; (b) erythrocyte ghosts treated with $2.5 \mu \mathrm{g}$ pronase; $(c)$ untreated erythrocyte ghosts (for conditions see Methods).

\section{RESULTS}

Effects of $\alpha$-toxin and of proteolytic enzymes on the rabbit erythrocyte membrane. The densitometer traces illustrated in Fig. I show the patterns of polypeptides before and after treatment of erythrocyte ghosts with $\alpha$-toxin. The toxin alone (Fig. I $c$ ) shows two main components, the major one corresponding to the biologically active toxin monomer $\left(\alpha_{3 s}\right)$ and the minor slow moving band corresponding to the $\alpha_{12 s}$ polymer (see McNiven et al. 1972; Arbuthnottet al. I973). After interaction of $\alpha$-toxin with erythrocyte ghosts, the pattern of membrane polypeptides (Fig. I $a$ ) was very similar to untreated control ghost preparations (Fig. I $b$ ) apart from the presence of additional peaks which can be accounted for by the $\alpha$-toxin itself. It is noteworthy that in addition to the appearance of the toxin peaks in traces of toxin-treated ghosts, the positions of the two toxin peaks remain unchanged after interaction, although there is an increase in the amount of slow moving polymer and a corresponding decrease in the faster moving monomer.

Treatment of ghosts with pronase, however, causes very major alterations in the pattern of membrane polypeptides. Indeed, interaction with small amounts ( 10 to $100 \mu \mathrm{g}$ ) of pronase for times longer than a few minutes resulted in so much digestion of ghost proteins that the resultant peptides are not detectable in gels run under the conditions described. The largest of the resultant peptides are small enough to travel completely through the gel, as evidenced 
Table I. Comparison of the action of staphylococcal $\alpha$-toxin and proteolytic enzymes on rabbit erythrocyte ghosts

$\begin{array}{cc}\text { Treatment (Methods) } & \begin{array}{c}\text { Change in ghost } \\ \text { protein }(\%)\end{array} \\ \text { Pronase } & -54 \cdot 7 \\ \text { Subtilisin } & -52 \cdot 1 \\ \text { Trypsin } & -22 \cdot 0 \\ \text { Chymotrypsin } & -18 \cdot 5 \\ \text { Staphylococcal } \alpha \text {-toxin } & +9 \cdot 0 \\ \text {-, Reduction in sedimentable protein; }+ \text {, increase in sedimentable protein. }\end{array}$

by the complete absence of stainable material at the termination of the run (Fig. $2 a$ ). When the amount of enzyme was reduced to $2.5 \mu \mathrm{g}$, partially digested membrane polypeptides were detected in the lower half of the separating gels only (Fig. $2 b$ ).

Thus, under these conditions, no proteolytic activity was detected following the interaction of erythrocyte membrane with $\alpha$-toxin, yet the effects of small amounts of proteolytic enzyme on the pattern of membrane polypeptides was readily demonstrable by this technique.

The qualitative changes in polypeptide patterns described above were estimated quantitatively by following changes in the sedimentable ghost proteins after proteolytic enzyme treatments. Table I shows the relative reductions in sedimentable ghost protein after treatment of ghosts with a variety of proteolytic enzymes. Approximately half of the sedimentable protein associated with the washed erythrocyte membranes was released as non-sedimentable material after treatment with pronase and with Subtilisin. Trypsin and chymotrypsin although less active did release a considerable amount of ghost protein. In contrast to all the enzymes tested, $\alpha$-toxin resulted in an increase in sedimentable protein when compared with control ghost preparations. Moreover, treatment of whole rabbit erythrocytes with proteolytic enzymes (pronase, Subtilisin and trypsin) prior to the addition of toxin did not alter the kinetics of haemolysis. No alterations in the rate of haemolysis were detectable nor in the duration of the prelytic lag phase.

The observation that the presence of protease inhibitor (phenyl methane sulphonyl fluoride) at a concentration of $2 \times 10^{-3} \mathrm{M}$ did not affect the haemolytic titre of $\alpha$-toxin is further evidence for a non-proteolytic mechanism of haemolysis.

Electron microscopy of toxin-treated erythrocyte membranes. Interaction of $\alpha$-toxin with erythrocyte ghosts resulted in changes in the relative proportion of the toxin monomer and polymeric ring form (Freer et al. 1968). Fig. $3(b)$ shows a control ghost preparation before interaction with toxin, and Fig. $3(a)$ shows ghosts after toxin treatment. The abundance of ring structures, similar in appearance to the $\alpha_{12 \mathrm{~s}}$ polymer, confirms the results of our earlier study and supports the findings of the experiments involving disc electrophoresis (Fig. I $a$ ). Apart from fragmentation and the presence of ring structures, no further information relating to the mode of interaction can be gained from negatively stained preparations. In Fig. 4, however, the extent of toxin-induced damage to erythrocyte ghosts is more clearly demonstrated. The freeze-fractured replica shown in Fig. 4(a) illustrates the fracture planes in control ghost preparations. The ghosts appear relatively smooth in outline with the membranes largely intact. The appearance after toxin treatment is drastically altered (Fig. $4 b$ ), the outline being extremely irregular due to fragmentation and vesiculation of the membrane. A closer examination of the fractured membranes revealed several features which predominate in toxin-treated erythrocyte ghosts: (i) the fracture plane is 'stepped' with a relatively high proportion of it showing areas which appear as 'plaques' (Fig. $5 b$ ), 

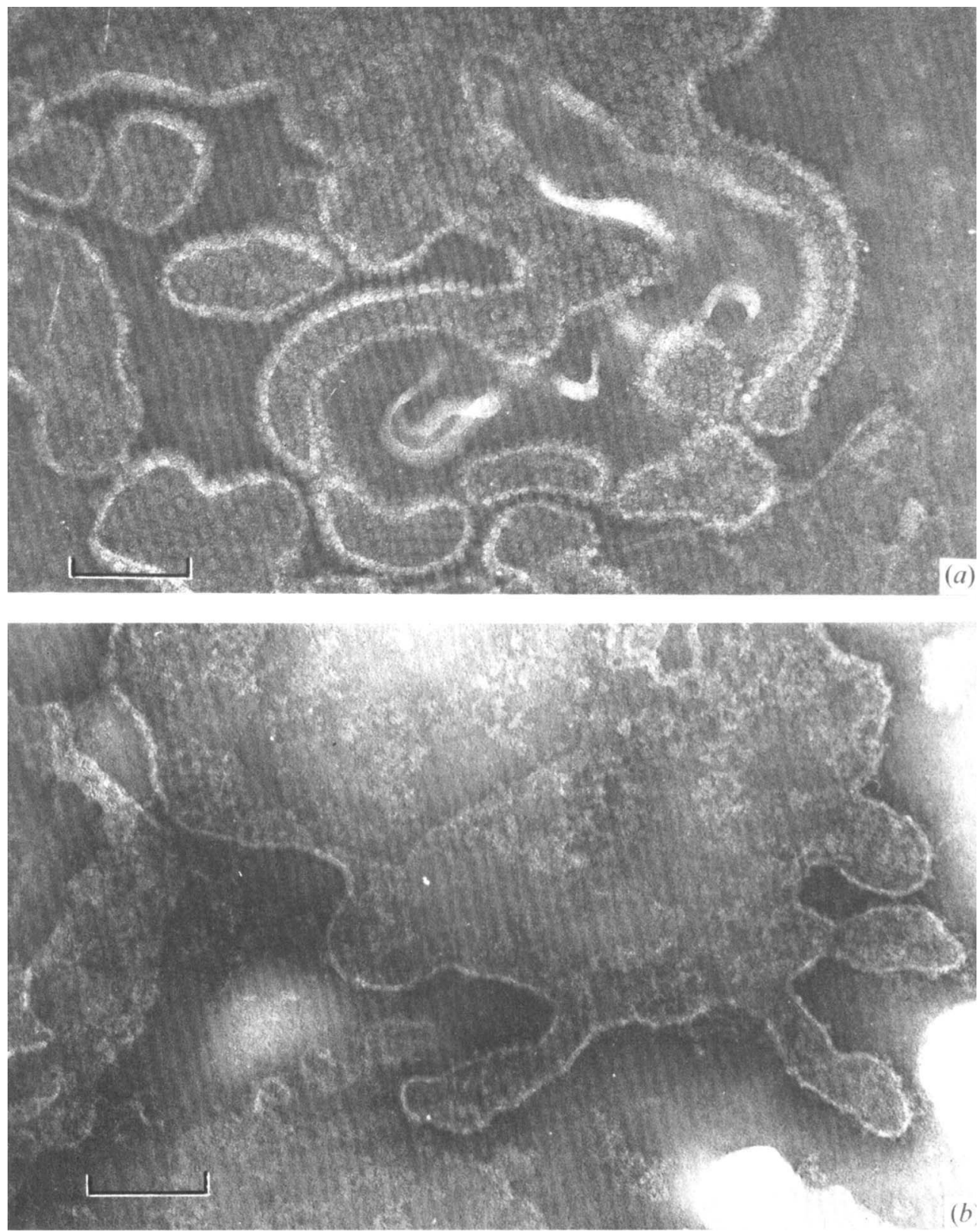

Fig. 3. Electron micrographs of negatively stained preparations of rabbit erythrocyte ghosts. Reaction mixtures contained $0.2 \mathrm{ml}$ of washed ghosts (Methods) and $0.1 \mathrm{ml}$ of either $0.03 \mathrm{M}$-sodium

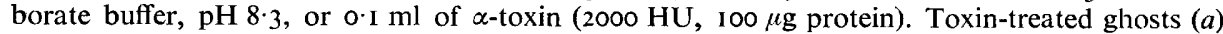
contained many fragments totally covered with ring structures, whereas the control sample $(b)$ shows a granulo-fibrillar substructure characteristic of such preparations. Bar represents $100 \mathrm{~nm}$. 



Fig. 4. Low magnification electron micrographs of replicas of frozen-etched rabbit erythrocyte ghosts. Reaction mixtures contained $0.2 \mathrm{ml}$ of washed erythrocyte ghosts together with $(a) 0.02 \mathrm{ml}$

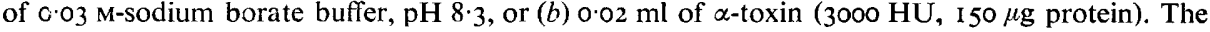
mixtures were incubated for $5.5 \mathrm{~min}$ at $22{ }^{\circ} \mathrm{C}$ before freeze-etching. Encircled arrow indicates direction of shadowing. Bar represents $5.0 \mu \mathrm{m}$.

contrasting with the relatively smooth areas found in control preparations (Fig. 5a); (ii) the surfaces of 'plaques' bear relatively few intramembrane particles; (iii) in membranes subjected to prolonged exposure $(30 \mathrm{~min})$ to $\alpha$-toxin, tangential fractures through the membrane were rare, with cross-fractures being the characteristic feature; (iv) smooth elevations and depressions were often seen in regions of 'plaque' formations (Fig. $5 b$ ); (v) the outer surface of the membrane exposed by etching showed the presence of particles (Fig. $5 c$ ) not seen in control preparations. These are interpreted as being the polymeric form of the toxin seen as ring structures in negatively stained preparations.

Rabbit erythrocytes fixed with glutaraldehyde at the onset of toxin-lysis were examined in thin sections. Myelinic figures (Fig. 6) consisting of closely packed accumulations of membrane were a consistent feature of the surfaces of such cells.

\section{DISCUSSION}

Staphylococcal $\alpha$-toxin is one of several bacterial extracellular proteins which are cytolytic to varying degrees and which share the common feature of being bound by phospholipids (Arbuthnott, 1970). An understanding of the mechanism of action of this toxin would be of value, not only in increasing the knowledge about membrane-active substances of biological origin, but also from the point of view of its possible role in staphylococcal disease. 

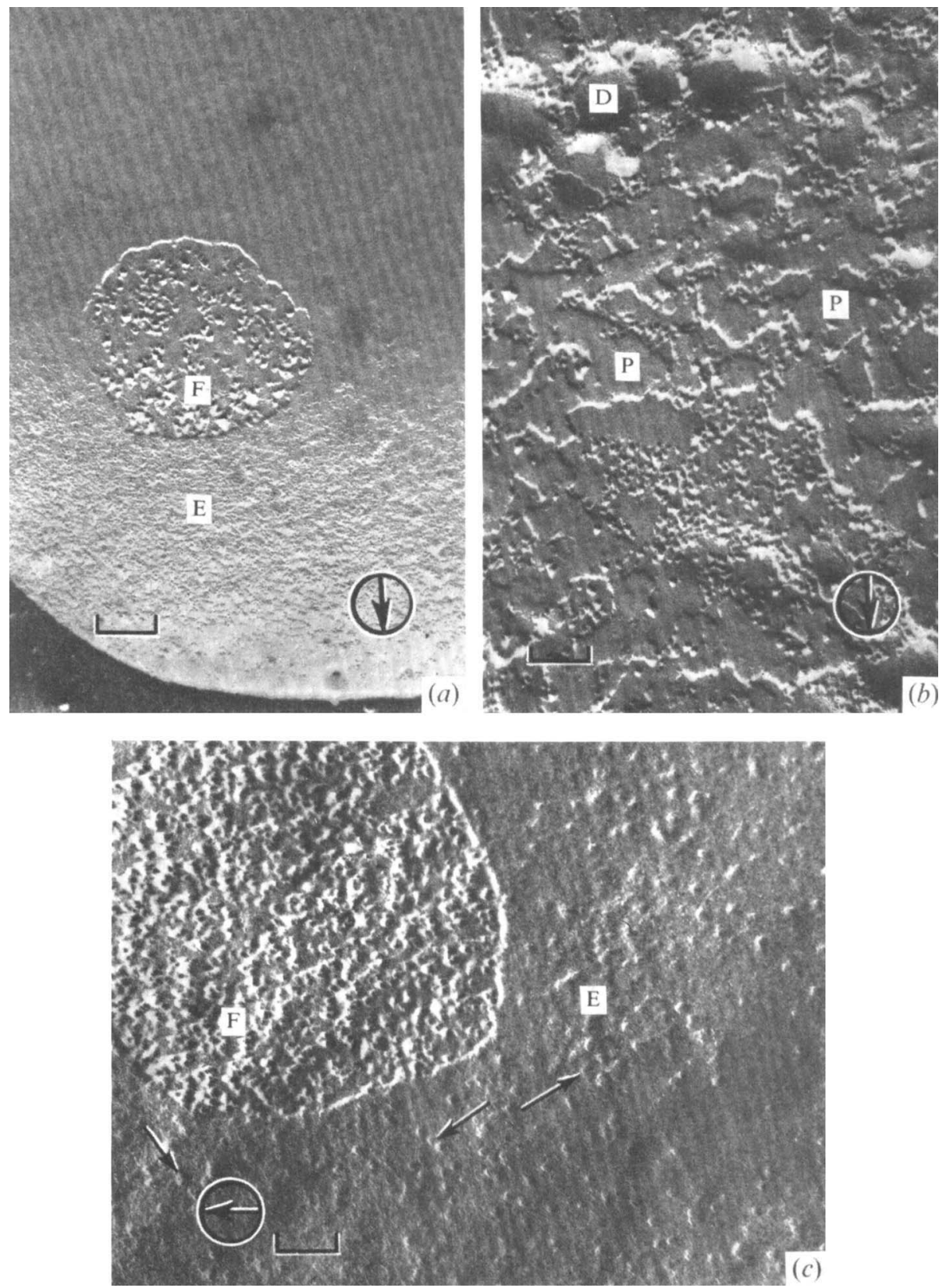

Fig. 5. High magnification electron micrographs of replicas of frozen-fractured rabbit erythrocyte ghosts. The particle-studded fracture face (F) and smooth outer surface of the membrane exposed by etching (E), typical of control preparations, are seen in Fig. 5(a) (reaction mixture same as that described for Fig. 4a). After exposure to $\alpha$-toxin for a short time (40 s), the fracture face seen in Fig. $5(b)$ contained areas of 'plaque' formation (P) and smooth depressions (D). The reaction mixture in this case contained $0.1 \mathrm{ml}$ of washed erythrocyte ghosts and $0.02 \mathrm{ml}$ of $\alpha$-toxin $(400 \mathrm{HU}$, $20 \mu \mathrm{g}$ protein). Toxin-treated membranes (prepared as described for Fig. $4 b$ ) exhibited numerous particles (arrows) on the outer membrane face exposed by etching (Fig. $5 c$ ). Encircled arrow indicates direction of shadowing. Bar represents $100 \mathrm{~nm}$. 


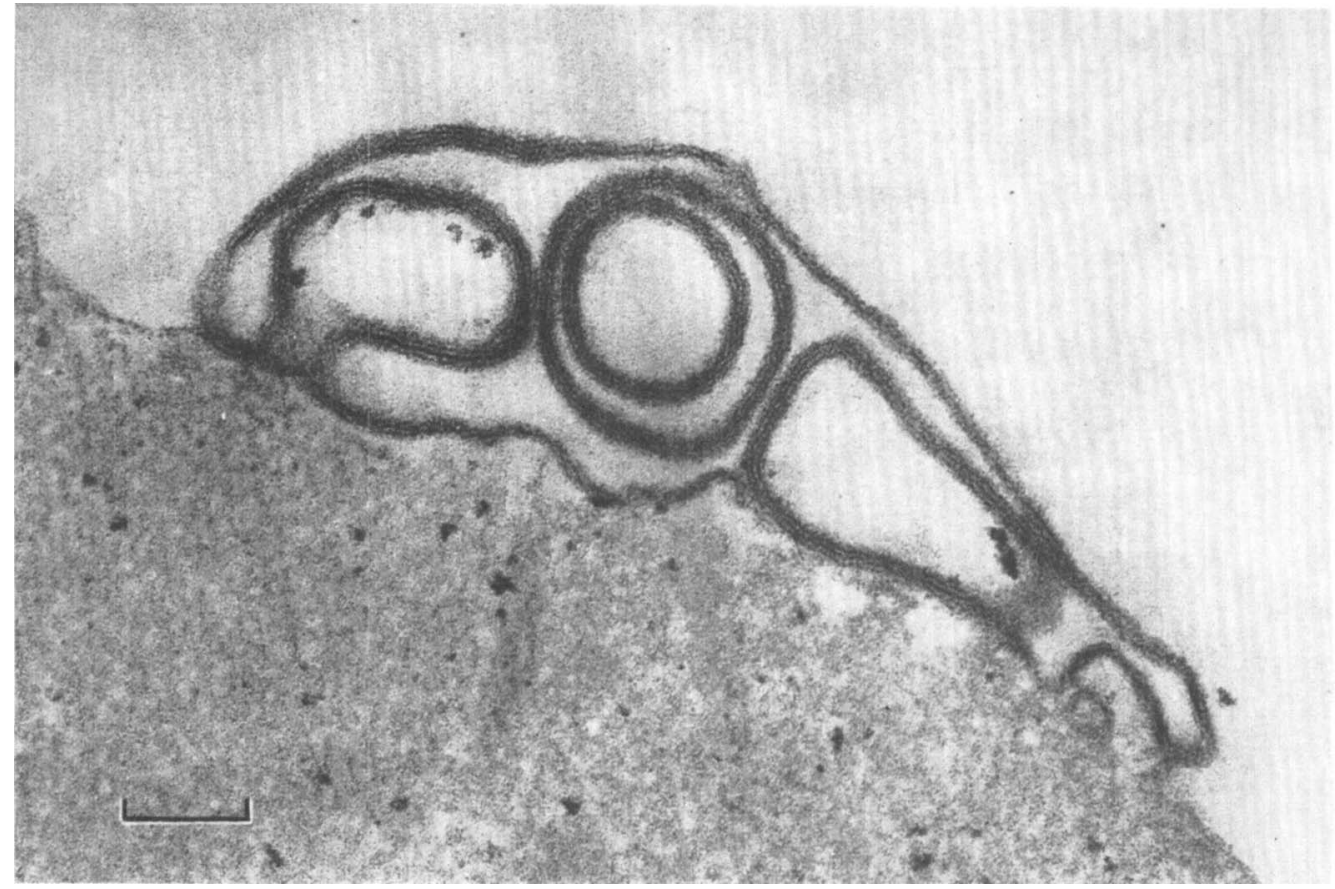

Fig. 6. Electron micrograph of a thin section of toxin-treated rabbit erythrocytes showing a 'myelinic' membrane formation attached to the cell surface. Bar represents $100 \mathrm{~nm}$.

Earlier work suggested that the toxin is a protein of relatively high surface activity (Freer et al. I968) and this has since been shown beyond doubt (Buckelew \& Colacicco, I97I; Colacicco \& Buckelew, I97I). A cytolytic mechanism dependent upon this surface active property would not be unique among biological toxins, since melittin, the major component of bee venom, is a highly surface active peptide and is thought to be cytolytic by virtue of its amphipathic nature (Sessa, Freer, Colacicco \& Weissmann, 1969). Recently, however, Wiseman \& Caird (1970, 1972) have concluded that a proteolytic mechanism is involved in the action of staphylococcal $\alpha$-toxin. They suggest that the toxin is an inactive protease, activated by proteolytic enzymes associated with the erythrocyte membrane.

Our data do not support this suggested mechanism since erythrocyte ghosts treated with $\alpha$-toxin showed: (i) no alteration in the pattern of polypeptides as assessed by disc electrophoresis; (ii) no decrease in sedimentable protein; and (iii) a distribution of intramembrane particles in freeze-fractured ghosts unlike that observed after treatment with known proteolytic enzymes (Branton, I97I ; Speth, Wallach, Weidekamm \& Knüfermann, 1972). Furthermore, the presence of protease inhibitor did not reduce the haemolytic titre of toxin, nor did prior treatment of whole erythrocytes with pronase, trypsin, or chymotrypsin alter the kinetics of toxin haemolysis.

In contrast with the absence of detectable proteolytic activity associated with $\alpha$-toxin, the effects of proteolytic enzymes on erythrocyte ghosts were easily demonstrated. For example, small quantities of pronase caused marked alterations in the pattern of membrane polypeptides seen in disc electrophoresis. Also the effects of pronase, Subtilisin, trypsin and chymotrypsin on ghosts were evident from the reduced values obtained for sedimentable protein after enzyme treatment. The slight increase in the value for sedimentable protein 
noted after treatment of ghosts with $\alpha$-toxin can be accounted for by the absorption of toxin, a process known to occur on both natural and artificial membranes (Freer et al. I968; Arbuthnott et al. 1973).

In recent years the technique of freeze-fracturing has been applied extensively in the study of biological membranes (Branton, I971 ; Moor, I97I). In this process, the membranes are physically fixed by low temperature and cleavage is thought to follow the interior apolar plane of the membrane, where hydrophobic stabilizing forces have been reduced due to low temperature. This fracture plane reveals the interior of the membrane, which normally appears as a continuous surface carrying numerous intramembrane particles. Removal of ice by sublimation (etching) exposes the outer faces of the membrane which are relatively smooth and particle-free. The changes in the fracture plane resulting from the action of staphylococcal $\alpha$-toxin resemble closely those described by Speth et al. (I972) in human erythrocyte ghosts treated with phospholipase A and with saponin.

Although these authors used phospholipase A, they presented evidence to show that the observed changes in the fracture plane were not a consequence of enzymatic hydrolysis of membrane phospholipids. The characteristic changes in the fracture plane, namely the occurrence of areas showing plaque formations, were thought to be due to alternation of the fracture plane between closely adherent membranes (Speth et al. I972). The plaques seen in $\alpha$-toxin-treated membranes probably arise by a similar process, the deflection of the fracture from one hydrophobic plane to another occurring in regions where penetration of toxin has taken place. Indeed, membranes in close apposition are frequently observed as myelinic figures in thin sections of erythrocytes undergoing toxin-lysis. The fact that the surface of plaques appear smooth and bear few intramembrane particles suggests that the apposing membranes in such areas differ structurally. Moreover, prolonged treatment of membranes with $\alpha$-toxin results in a predominance of membrane cross-fractures. Treatments known to disrupt the hydrophobic regions of membranes, for example, high levels of saponin, lysolecithin or sodium dodecyl sulphate (Speth et al. 1972) or extraction with acetone (Branton \& Park, I967; Branton \& Southworth, 1967) also produce this effect.

The possible involvement of an enzymatic mechanism in the cytolytic action of staphylococcal $\alpha$-toxin cannot be excluded, since the detection of products of enzymatic action in such a complex and chemically heterogeneous system may not be feasible at present. The large number of possible substrates, many of which have not been chemically characterized, and the possibility of endogenous enzymatic activity, together with structural rearrangements known to occur during the isolation of cell membranes (see review by Wallach, 1972) all add to the problems of specifying the mode of action of cytolytic proteins.

The results of this study serve to eliminate membrane proteins as substrates or receptors for $\alpha$-toxin, and support earlier suggestions (Freer et al. 1968; Buckelew \& Colacicco, 197 I) that the surface active properties of this toxin play a major role in its mode of action.

This work was supported by grants from the Medical Research Council and the Royal Society. The authors gratefully acknowledge the assistance of Ian McKee in preparing the illustrations. 


\section{REFERENCES}

ArbuthnotT, J. P. (1970). Staphylococcal $\alpha$-toxin. In Microbial Toxins, vol. III, pp. I89-236. New York and London: Academic Press.

Arbuthnott, J. P., Freer, J. H. \& Billcliffe, B. (1973). Lipid-induced polymerization of staphylococcal x-toxin. Journal of General Microbiology 75, 309-319.

BERG, H. C. (I969). Sulfanilic acid diazonium salt; a label for the outside of the human erythrocyte membrane. Biochimica et biophysica acta $\mathbf{1 8 3}, 65-78$.

Branton, D. (I971). Freeze-etching studies on membrane structure. Philosophical Transactions of the Royal Society of London, B 26r, 133-1 38.

Branton, D. \& PARK, R. B. (1967). Subunits in chloroplast lamellae. Journal of Ultrastructure Research I9, 283-303.

Branton, D. \& Southworth, D. (1967). Fracture faces of frozen Chlorella and Saccharomyces cells. Experimental Cell Research 47, 6I 8-653.

BRENNER, S. \& HoRne, R. W. (1959). A negative staining method for high resolution electron microscopy of viruses. Biochimica et biophysica acta 34, 103-I IO.

Buckelew, A. R. \& Colacicco, G. (I97I). Lipid monolayers. Interactions with staphylococcal $\alpha$-toxin. Biochimica et biophysica acta 233, 7-16.

COLACICCO, G. \& BuCKELEW, A. R. (I971). Lipid monolayers. Influence of lipid film and urea on the surface activity of staphylococcal $\alpha$-toxin. Lipids $6,546-553$.

DeVito, E. \& Santomé, J. A. (1966). Disc electrophoresis of proteins in the presence of sodium dodecyl sulphate. Experientia 22, 124-125.

Freer, J. H., Arbuthnott, J. P. \& Bernheimer, A. W. (I968). Interaction of staphylococcal $\alpha$-toxin with artificial and natural membranes. Journal of Bacteriology 95, I $153-1$ I 68.

Freer, J. H., Kim, K. S., Krauss, M. R., Beaman, L. \& Barksdale, L. (1969). Ultrastructural changes in bacteria isolated from cases of leprosy. Journal of Bacteriology 100, 1062-1075.

Hoogeveen, J.Th., Juliano, R., Coleman, J. \& Rothstein, A. ( 1970). Water soluble proteins of the human red cell membrane. Journal of Membrane Biology 3, 156-1 72.

Kellenberger, E., Ryter, A. \& SÉchAud, J. ( I958). Electron microscope study of DNA-containing plasms. II. Vegetative and mature phage DNA as compared with normal bacterial nucleoids in different physiological states. Journal of Biophysical and Biochemical Cytology 4, 67I-678.

Lowry, O. H., Rosebrough, N. J., Farr, A. C. \& Randall, R. J. (195I ). Protein measurement with the Folin phenol reagent. Journal of Biological Chemistry I93, 265-275.

MCNiven, A. C., Owen, P. \& Arbuthnott, J. P. (1972). Multiple forms of staphylococcal $\alpha$-toxin. Journal of Medical Microbiology 5, $113-122$.

Moor, H. (I97I). Recent progress in the freeze-etching technique. Philosophical Transactions of the Royal Society of London, B 26r, I 2 I-I 32.

Sessa, G., Freer, J. H. Colacicco, G. \& Weissmann, G. (1969). Interaction of a lytic polypeptide, melittin, with lipid membrane systems. Journal of Biological Chemistry 244, 3575-3582.

Speth, V., Wallach, D. F. H., Weidekamm, E. \& Knüfermann, H. (1972). Micromorphologic consequences following perturbation of erythrocyte membranes by trypsin, phospholipase A, lysolecithin, sodium dodecyl sulphate and saponin. A correlated freeze-etching and biochemical study. Biochimica et biophysica acta 255, 386-394.

WALlACH, D. F. H. (I972). The dispositions of proteins in the plasma membranes of animal cells: analytical approaches using controlled peptidolysis and protein labels. Biochimica et biophysica acta 265, 6I-83.

Wiseman, G. M. \& CAIRD, J. D. (1970). Mode of action of the $\alpha$-toxin of Staphylococcus aureus. Canadian Journal of Microbiology $\mathbf{6 ,}$, 47-50.

Wiseman, G. M. \& CAIRD, J. D. (1972). Further observations on the mode of action of the $\alpha$-toxin of Staphylococcus aureus 'Wood 46'. Canadian Journal of Microbiology 18, 987-992. 